\title{
The Students' Ability in Expressing Gratitudeand Appreciation by Using Think Pair Share Strategy at Sixth Grade Students of SD Yabes School Medan
}

\author{
Marice Saragih $^{1}$, Jonris Tampubolon ${ }^{2}$ \\ AMIK Widyaloka ${ }^{1}$, Universitas Prima Indonesia ${ }^{2}$ \\ maricesaragih79@gmail.com \\ john89tpb@gmail.com
}

\begin{abstract}
The objectives of this research are to find out the students ability in expressing gratitude and appreciation by using Think-Pair-Share Strategy and to find out the achievement levels of the students ability in expressing gratitude and appreciation by using think pair share strategy at the sixth grade students of SD Yabes School. The good teacher is able to find the good strategy in the teaching and learning process so that the students will interest to study English. One of strategy used in teaching speaking ability in express gratitude and appreciation is Think-Pair-Share Strategy. The population of this study was all of the sixth grade students of SD Yabes School which consist of 30 students, all the population used as the sample so that the sample consist of 30 students. This study use quantitative research using an experimental design and control design, the examiner intentionally revised appearance of the difference and then it was examined how the result was. This research required two groups of student namely experimental group and control group. experimental group was treated with Think-Pair-Share Strategy during speaking. where as control group was treated without Think-PairShare. From the total score pre test of the experimental class (1.600) and the total score pre test of the control class (1.360) can be concluded that the achievement of both group was the same. After getting the treatment (Thik-Pair-Share), the total score post-test of the experimental (2.337) was higher than the total score post-test of the control class (1.686) which did not get the treatment. It can be said that teaching Think-Pair-Share gave positive effect on the students, speaking achievement in expressing gratitude and appreciation
\end{abstract}

Key Words : Gratitude and Appreciation, Think-Pair-Share Strategy

\section{Introduction}

Gratitude is the general expression used to express thanking to people who gave us something. This expression often heard in our daily life. While appreciation is the expression used to appreciate gift of people, it is also often heard and often expressed to people in our daily life and it is not strange again for us (Hariyono, 2006:93).Those expression will make the students be motivated to study. The teacher who is able present the material easily will be students' idol. The teacher can use picture and dialog in teaching learning process to help the students' understanding about the material that is explained.

So, to make the students have strong interest in teaching and learning process especially in learning speaking, the teacher should take the best approach, method, and strategies. Then, the teacher can use gratitude and appreciation in teaching of English language, both are used to help the students for speaking to make interaction between the students with students.

The research is interested in investigating the students' ability in expressing gratitude and appreciation in speaking ability because she wanted to know the students' ability in expressing gratitude and 
appreciation in speaking by using think-pair-share strategy. Gratitude and appreciation can be designed for foreign language teaching to improve the students ability in speaking.

Example in conversation form:

Students : Excuse me, Sir.

Teacher : Yes, what can I do for you?

Students : I don't understand this sentence. Could you explain me again?

Teacher : Certainly

Students : : Thank you for your help. You are very kind.

Teacher : I'm glad I could help.

Think Pair Share teaching strategy is a strategy to accustom students practice in speaking by their ideas. Think Pair Share strategy can guide the students to their prior knowledge and make the students active in participating classroom discussion The importance of self-confidence to accustom students or learners is crucial part in leaning speaking English. This can achieve teaching material and activities can give enthusiasm, brave and stimulation to the learners, when the teacher present the material and ask student to perform with their ideas, they will not to monotonous and boring in learning process.

Based on the above description the research decides to investigate this phenomena entitled 'students' ability in expressing gratitude and appreciation in speaking by using Think-Pair- Share strategy.

\section{Gratitude and Appreciation}

Gratitude is the general expression used to express thanking to people who gave us something. This expression often heard in our daily life. While appreciation is the expression used to appreciate gift of people, it is also often heard and often expressed to people in our daily life and it is not strange again for us (Hariyono, 2006:93).In other hand, gratitude and appreciation can make in helping the students to communicate that is to understand, to speak, to read, to listen, and to write English. Furthermore, these expressions are as means to facilitate, and motivate students with presenting any skill of language in classroom activities.

This study discusses about definition of gratitude and appreciation, kinds and usage of gratitude and appreciation.Gratitude is the feeling of being grateful of the desiring to express one's thanks (Oxford dictionary). While according to Hariyono (2006: 92) gratitude is the general expression used to express thanking to people who gave us something. This expression often heard in our daily life. All of us also often use it very time when we got something from people.

Appreciation is the feeling or showing gratitude to appreciate gift from people (Oxford dictionary). The other opinion stated that appreciation is the expression used to appreciate gift of people, it is also often heard and often expressed to people in our daily life and it is not strange again for us (Hariyono, 2006: 93).

In this study, the researcher asked the students to express gratitude such as "Thank you very much", and appreciation such as "it's very good of you". After analyzed the students' speaking ability, the students were able to express and respond those expression well especially in speaking English. Therefore, gratitude and appreciation can help the students in improving their mastery in communication, especially in speaking English.The expression of gratitude used in the formal situation such as; thank you, thank you very much, thank you for your help, thank you for your tips, etc. replying for gratitude in the formal situation such as; you are welcome, it was my pleasure, don't mention it, etc. while the expression of appreciation can used in the formal and informal situations (Hariyono, 2006: 98). While the expression of gratitude used informal situations, such as; much obligated, I can't thank you enough, I can't find words how to thank you. Replying for gratitude in formal situation such as, not at all, no problem, thank you just the same, okay, the same, and forget it (Hariyono, 2006: 98).

The formal situation is usually used by student with teacher, employee with boss, student with advisor, younger with older and patient with doctor. While the informal situation is used by student with student, friend with friend, husband with wife, etc. (Hariyono, 2006: 99).

Examples of the conversation used gratitude and appreciation

\section{Student with Teacher}

Student : $\quad$ Excuse me sir, can I borrow your pen? 
Teacher : $\quad$ Sure, but where is your pen?

Student : I'm sorry sir my pen is lost last time. I don't know who is

Take it. I put it in my bag, but after I want to use it for writing suddenly I didn't find it.

Teacher : $\quad$ Okay, I will lend you but you must be careful next. Here you are.

Student : Yes sir. Thank you very much. It's very good of you.

Teacher : You are welcome.

\section{Employee with boss}

Employee : I am sorry sir i want to ask about the meeting now. what topic our meeting now?

Boss : Where are you ask me now?

Employee : Because I absent yesterday.

Boss : I always hope that you always present everyday.

Employee : Once again I am sorry Sir, Can you repeat again?

Boss : Okay, our meeting now speak about building of hotel near beach.

Employee : Thank you for your information, Sir. You are very kind.

Boss : Don't mention it.

\section{Patient with doctor}

Doctor : What is your name?

Mr. Ahmad : My name is Ahmad

Doctor : What's wrong with you?

Mr. Ahmad : I feel very bad cold but my body is very warm. I ever to the other doctor, he said that I get typhus. I am very sad with my sick.

Doctor : : I am sorry to hear that.

Mr. Ahmad : Thank you for your sympathy.

Doctor $\quad$ : Don't be sad. I will give your medicine, I hope you will get better soon.

Mr. Ahmad : Thank you for your tips. You are very kind.

Doctor : It was my pleasure.

\section{Student with advisor}

Student $\quad$ : Sir, can you tell me to solve my problem? I am very confuse about that.

Advisor : Of course. What is your problem?

Student $\quad$ : I don't understand aboutthis sentences. Can you explain me again?

Advisor $\quad$ : Yes, I can. You must study hard about that. You must change the sentence into past tense sentence.

Student $\quad$ : Thank you, Sir. It's very kind of you.

Advisor : You are welcome.

\section{Informal situation}

\section{Student with Student}

A : : Good morning friend. How are you this morning?

B : : Good morning, I'm fine' and you?

A : I am fine too. Where are you going?

B : I go to library, and you?

A : I go to library too.

B : I I think you will go to canteen.

A : : Friend, can you help me get book of health?

B : Sure. Let's go now

A : Much obliged. You are very kind.

B : Forget it.

\section{Friend with Friend}

Published by English Lecturers and Teachers Association (ELTA)

Copyright (C) 2021, authors 


\begin{tabular}{lll}
\hline A & $:$ & What are looking for? \\
B & $:$ & I am looking for my bag. \\
A & $:$ & Do you need help me? \\
B & $:$ & Sure, thanks a lot. \\
A & $:$ & This is your bag. I get in the table near selves. \\
B & $:$ & I can't thank you enough. \\
A & $:$ & Not at all
\end{tabular}

\section{Kinds and Usage of Gratitude and Appreciation}

Gratitude used when we got something from people, and it was used to appreciate their gift. According to Hariyono (2006 : 92), the kinds and replying of gratitude are as follow :

The kinds of gratitude Replying

\begin{tabular}{ll}
\hline \multicolumn{1}{c}{ Formal form } & \multicolumn{1}{c}{ Formal form } \\
Thanks & You are welcome \\
Thank you & I am glad I could do it \\
Thank you very much & I am glad I could be of help \\
Thank you so much & Don't mention it \\
Thanks a lot & I am glad I could help \\
I don't know how to thank you & Glad to be of help \\
Thank you for your help & It was my pleasure \\
Ttahnk you for your tips & Okay, the same \\
& \\
\multicolumn{1}{c}{ Informal form } & \multicolumn{1}{c}{ Informal form } \\
& Not at all \\
Much obliged & Thank you just the same \\
I can't thank you enough & Forget it \\
I can't find words how to thank you
\end{tabular}

\section{Think-Pair-Share (TPS)}

Think -Pair-Share Strategy provides an opportunity for all students to share their thinking with at least one other students, in turn, increases their sense of involvement in classroom learning .The Think-PairShare strategy is designed to differentiate instruction by providing students time and structure for thinking on a given topic, enabling them to formulate individual ideas and share these ideas with a peer. This learning strategy promotes classroom participation by encouraging a high degree of pupil response, rather than using a basic recitation method in which a teacher poses a question and one student offers a response. Additionally,. Think-Pair-Share can also be used as in information assessment tool; as students discuss their ideas, the teacher can circulate and listen to the conversations taking place and respond accordingly. In this strategy, a problem is posed, students have time to think about it individually, and then they work in pairs to solve the problem and share their ideas with the class. Think-Pair-Share is a grouping strategy that lets students collaborate on ideas, opinions, research topics, problem-solving procedures, debate resolutions, textual analyses, and small group activities (Slavin, 2005:24). Slavin (2005) purposes this strategy in order to solve or at least to minimize students' problems. Think Pair Share teaching strategy is a strategy to accustom students practice in speaking by their ideas. Think Pair Share strategy can guide the students to their prior knowledge background and make the students active in participating classroom discussion. The importance of self-confidence for learners is crucial part in leaning speaking English. This can achieve teaching material and activities that can give enthusiasm, brave and stimulation to learners, when the teacher present the material and ask student to perform with their ideas, they will not to monotonous and boring in learning process. Dornyei (2001) suggests that the ways to promote students' self-confidence were through providing experience of success, encouraging the learners and reducing anxiety. The learners have to enthusiasm achieved the goal of learning a foreign language to success in mastery a target language well. Students 
having to high self-confidence will maximize the feedback to improve their speaking competency and reach their excellent goal in learning.

Procedures of Think-Pair-Share Strategy According Slavin(2005), there are four steps of Think-pairshare procedure, they are: 1 . Step One - Teacher poses a question. The process of think-pair-share begins when the teacher poses a thought-provoking question for the entire class. This may be a straight forward question or a problem the teacher wants to pose to the class for solution. Questions must pose problems or dilemmas that students will be willing and bale to think about. 2. Step Two - students think individually. At a signal from the teacher, students are given a limited amount of time to think of their own answer to the problematic question. The time should be decided by the teacher on the basis of knowledge of the students, the nature of the question, and the demands of the schedule. It may be helpful, though it is not required, to have students write out their individual responses and solutions. Students should understand that while there may be no one right answer, it is important that everyone come up with some reasonable answer to the question. This step of the procedure automatically builds "wait time' into the classroom conversation. 3. Step Three - Each students discusses his or her answer with a fellow students. The end of the think step signal to the students the time to begin working with one other students to reach consensus on an answer to the question. Each student now has a chance to try out possibilities. Together, each pair of students can reformulate a common answer based o their collective insights to possible solutions to problem. At times, the process can go one step farther by asking pairs of students to regroup into foursome to further refine their thoughts before sharing with the group at large. These small group settings are less threatening to individual students than venturing forward before the whole group with an untried answer. The pair step in the model also promotes much more conversation among students about the issues entailed by the question. 4 . Step four - Students share their answer with the whole class.

In this research the writer ask the student to think about the topic that the teacher share about gratitude and appreciation, then student practice with their friend in pair after that the student share the topic of the conversation about the gratitude and appreciation to the class as a whole. It allows students time to formulate their thought and involves all students, not just a few who volunteer or whom the teacher calls on. Think-Pair-Share work well in the classes and can be adapted for all levels, beginners to college level. It can easily be implemented in large classes.

\section{Research Methodology}

In this study, the researcher used quantitative research. This study prepared or sets up communication strategies toward speaking fluency. For the students who were examined to answer speaking that would be tested. The idea concerned with the statement of Arikunto (1998: 67) says that by using an experimental design and control design, the examiner intentionally revised appearance of the difference and then it was examined how the result was. This research required two groups of student namely experimental group and control group. experimental group was treated with role play technique during speaking. where as control group was treated without Think-Pair-Share

\section{Population and Sample}

Population is the number of people, which have the same characteristic (Arikunto, 1998). Moreover she states that a population is a set of collection, all elements processing one or more attributes of interest. Based on definition above, the researcher inferred that population was the entire subject of study which was examined. So, the population of this study was all The number of at sixth grade Elementary School at The YabesSchoolconsists of 30 students .Arifin $(2003 ; 6)$ defines sample as some of population that present the whole population. Kind of sampling is used in this study was quota sample it is not done base of the area, but based on number determined. In taking the sample are all the student of of sixth grade Elementary School at The Yabes School which consists of 30 students

\section{Instrument of data collection}

In this study the researcher used interview test as the instrument for collecting data. The interview test was conducted in both groups: Experimental and Control group.The accuracy of the result was very determined on how accurate the use of instrument. Relating to researcher used oral test as an instrument. Ary 
$(2005 ; 216)$ states that a test is a set of stimuli presented to an individual in order to elicit responses on the basis of which a numerical score can be assigned. Moreover Heaton(2007; 89) states that the test must be appropriate in terms of our objectives, it depends on the evidence provide and particular situation.

In order to avoid misunderstanding in the readers' mind, the researcher informed the kind of test that used in this research was speaking test as an instrument. The aim of it was to measure the skill, knowledge, ability, etc. the statement in situation form was used to stimulate the subject to build their opinion and the subject changed the situation into the conversation form.

\section{Technique of Data Collection}

In order to get data, the researcher administrated the way of collecting data as follows, The writer prepared statement in situation form which focused in gratitude and appreciation. Then the students practiced the situations into conversation form with their partner. It means that they changed the situations into conversation form. While, the students were doing conversation, the researcher recorded them by using tape recorder. Before practice the conversation, the students were given 15 minutes to study the situations, and practiced the conversation in 20 minutes. Then the writer gave the score based on the result of the record.

\section{Result and Discussion}

The data were taken from the result of sample's speaking test. The data were divided into two groups namely experimental and control group. Both experimental and control group were given speaking test form on pre-test and post-test. The students' score we obtained. The following is the result of the pre- test and post-test of both experimental and control group.

Table.1.The result of experimental group

\begin{tabular}{cccc}
\hline $\begin{array}{c}\text { The Amount of } \\
\text { The Students }\end{array}$ & $\begin{array}{c}\text { Mean of the } \\
\text { Pre-Test }\end{array}$ & $\begin{array}{c}\text { Mean of the } \\
\text { Pre-Test }\end{array}$ & Deviation \\
\hline 30 & 53,35 & 77,90 & 24,55 \\
\hline
\end{tabular}

From the table.1.above, it can be seen the mean of the score in the experimental group, from pretest (53.35) to post-test (77.90). So the deviation is 24.55.Mean of deviation of the experimental group is 24,55 it means that the deviation is high. This group was taught by using Think-Pair-Share

Table.2.The Result of the Control Group

\begin{tabular}{cccc}
\hline $\begin{array}{c}\text { The Amount of } \\
\text { The Students }\end{array}$ & $\begin{array}{c}\text { Mean of the } \\
\text { Pre-Test }\end{array}$ & $\begin{array}{c}\text { Mean of the } \\
\text { Pre-Test }\end{array}$ & Mean of Deviation \\
\hline 30 & 45,35 & 56,20 & 10.85 \\
\hline
\end{tabular}

From the table .2.above, it can be seen that the mean score of the pre-test in the control group is 45.35 and the post-test 56.20 , and mean of deviation is 10,85 . it means that the deviation is low. This group was taught without Think-Pair -Share Strategy. The writer used think-pair-share strategy in expressing gratitude and appreciation .

Think-Pair-Share is one of teaching strategies as a tool to increase the students' speaking achievement. Think-Pair-Share can make the students active when learning English in the classroom, before the strategy was applied for experimental group the writer gave the students in control group pre-test to see their ability. The next step was applied by using Think-Pair-Share strategy of this group. After applied the strategy, the writer gave the students post-test to see whether their ability in speaking would be affected by this strategy. 


\section{Discussion}

There were 30 students as the sample in the experimental and control groups. The writer choose this population because based on the writer's observation it was found that most of the students have minimum skill in learning English especially when the writer persuade them to speak English. Based on the writer observation, many students in Elementary School not interest to study English subject. It also happened on sixth grade Elementary School at the Yabes School. Their ability in English subject is lack. Actually they need a new learning style in teaching learning process. The result of the study indicated that teachers of English might be familiar with Think Pair Share on students' speaking achievement. Besides, the English teachers who are teaching English may use this information to develop a good skills in listening, speaking, reading and writing.In conducting the research, the writer found some experience problems from the students during the teaching and learning process, namely :the students are difficult in speaking English. To solve this, the writer taught them in treatment. And the researcher taught them by new strategy is Think-Pair-Share Strategy. In the middle of teaching and learning process, some of students were not interested to that lesson. To solve this, the writer gave the students motivation and jokes to build students spirit in the class. The data obtained from the score were the result of the experimental and control class. From the total score pre test of the experimental class (1.600) and the total score pre test of the control class (1.360) can be concluded that the achievement of both group was the same. After getting the treatment (Thik-Pair-Share), the total score post-test of the experimental (2.337) was higher than the total score post-test of the control class (1.686) which did not get the treatment. It can be said that teaching Think-Pair-Share gave positive effect on the students, speaking achievement in expressing gratitude and appreciation

\section{Conclusion}

The conclusion of this study are : the ability in expressing gratitude and appreciation by using Think-Pair-Share Strategy got higher score than the student taught without think-pair-share strategy. There is achievement levels of the students ability in expressing gratitude and appreciation by using think-pair-share strategy at the sixth grade students of SD YabesSchoo. In this case, both experiment and control classes were getting improvement in their post-test but the higher score was found when the student used think pair share strategy and the student enjoy to study English by using this strategy. There is a significant difference between the students' ability in experimental and control class to express gratitude and appreciation by using Think-Pair- Share Strategy. The calculation of the t-count was higher than the t-table

\section{REFERENCES}

Arikunto, Suharsimi. 2006. ProsedurPenelitian: SuatuPendekatanPraktik. Jakarta: PT. BinaAksara.

Ary, Donald. 2005. Introduction to Research in Education. New York: Northern Illionis University.

Crisper and Widdowson. 2004. Sociolinguistics and Language Taching. London: Oxford University Press.

Breen and Candlin. 1989. The Essentials of a Communicative Curriculum in Language Teaching. Washington D.C.: Georgetown University Press.

Brown, H.D. 2010.Principles of Language Learning and Teaching. New York: Cambridge University Press.

Gay, L.R. 1987. Educational Research: Competence for Analysis and Application. New York: Macmillan Brown Company.

Hariyono, Rudy. 2006. Serious English for Serious Student. Surabaya: Gitamedia Press.

Published by English Lecturers and Teachers Association (ELTA)

Copyright (C) 2021, authors 
Haryanto, Han. 1984. PendidikanBahasaInggris. Jakarta: Universitas Terbuka.

Heaton, JB. 1975. Writing English Language Test. Singapore: Longman Group Ltd.

Hornby, A.S. 2011.Oxford Advanced Learner's Dictionary of Current English. London: Oxford University Press.

Julia, M. Dobson. 1987. Effective Technique of English Conversation Group. Boston: English Language Programmer Dentition.

Netra, IB. 1978. MethodologiPendidikan. Singajara: FKIP UNUT.

Nurgiyantoro, Burhan. 1995. PenilaianDalamPengajaranBahasadan Sastra.Edisi II. Yogyakarta: BPFE.

Nurhadi, 2010.Kapita SelektaBahasadanSastra. Malang: IKIP Malang.

Nurkancana, Wayan and PPN.Sumartono. 1986. EvaluasiPendidikan. Surabaya: Usaha Nasional.

Oller, John W. 1979. Language Testing School. London: Longman Group Ltd.

Richard, Jack C. 2002. Methodology in Language Teaching: An Anthology of Current Practice.Cambridge University Press.

Ruga, 2002.The Watching English Films toward Speaking Skill. Mataram : IKIP Mataram. S.1 Thesis.Unpublished.

Suryabrata, Sumadi. 2002. PsikologiPendidikan. Jakarta: PT. Raja Grapindo Persada.

Slavin,R.E. 2005. Cooperative Learning :Theory Research and Practice. London

Tarigan, Henri Guntur. 2010. BerbicaraSebagaiKeterampilanBerbahasa. Bandung: Angkasa.

Published by English Lecturers and Teachers Association (ELTA)

Copyright (C) 2021, authors 